\title{
Digestible Energy Values of Diets with Different Fat Supplements when Fed to Lactating Dairy Cows*
}

\author{
W. P. Weiss and D. J. Wyatt \\ Department of Animal Sciences, \\ Ohio Agricultural Research and Development Center, \\ The Ohio State University, Wooster 44691
}

\section{ABSTRACT}

A total collection digestion trial using high producing lactating cows (average milk yield $=40.7 \mathrm{~kg} / \mathrm{d}$ ) was conducted to measure the effect of different fat supplements on dietary digestible energy (DE) concentrations and to calculate the DE value of the supplements. A diet with no supplemental fat, 2 diets with 1.75 or $3.5 \%$ (dry basis) Ca salts of palm fatty acids (Ca-PFA), and 2 diets with 1.6 or $3.2 \%$ hydrogenated triacylglycerides from palm oil (HPO) were fed in a $5 \times 5$ Latin square experiment with 28-d periods. Concentrations of supplemental long-chain fatty acids in the diets were 1.7 and $3.4 \%$ for the 2 supplementation rates. Dry matter intake was reduced when cows were fed the high concentration of Ca-PFA, but cows fed Ca-PFA produced more milk than cows fed the control diet or diets with HPO. The type or amount of fat supplementation did not affect measures of rumen fermentation or in situ fiber digestibility. Digestibility of energy, dry matter, and organic matter were higher for diets with Ca-PFA than for diets with HPO, mainly because of increased fatty acid digestibility. The dietary concentration of $\mathrm{DE}$ was similar between the control diet and diets with HPO (2.97 Mcal $/ \mathrm{kg})$, but it increased as the concentration of Ca-PFA increased (3.04 and $3.16 \mathrm{Mcal} / \mathrm{kg}$ for low and high supplementation rates). The calculated DE concentrations of the supplements averaged 7.3 and $3.1 \mathrm{Mcal} / \mathrm{kg}$ for Ca-PFA and HPO. The 2001 National Research Council dairy model accurately estimated DE concentrations in all diets ( $<1 \%$ difference).

(Key words: fat, digestibility, energy)

Abbreviation key: Ca-PFA = calcium salts of palm fatty acids, DE = digestible energy, LCFA = long-chain

Received October 28, 2003.

Accepted January 7, 2004.

Corresponding author: W. Weiss; E-mail: weiss.6@osu.edu

*Salaries and research support provided by state and federal funds appropriated to the Ohio Agricultural Research and Development Center, The Ohio State University. Additional financial support provided by Bonimex BV, The Netherlands. Manuscript No. 40-03AS. fatty acids, $\mathbf{H P O}=$ hydrogenated triacylglycerides from palm oil, $\mathbf{T D N}=$ total digestible nutrients .

\section{INTRODUCTION}

Supplemental fat is a common ingredient in the diets of high producing dairy cows (Kellogg et al., 2001). Although some fat supplements provide specific fatty acids that may be required by the cow, most fats are fed solely as an energy source. Based on historic feed prices in the US, the unit cost of energy from fat supplements is usually higher than that from feed grains. Therefore, to justify the use of supplemental fats economically, their inclusion must increase intake of $\mathrm{NE}_{\mathrm{L}}$ by dairy cows compared with the inclusion of other less expensive feedstuffs. The increased $\mathrm{NE}_{\mathrm{L}}$ intake must then either increase milk production or improve energy balance.

To make a rational decision regarding fat supplementation, the effect of fat supplements on energy intake must be estimated accurately. Numerous papers have been published quantifying the effects of fat supplementation on DMI as reviewed by Allen (2000). Based on a statistical analysis of literature data (added fatty acids ranged from about 1 to $6 \%$ of dietary DM), Allen (2000) reported that the addition of Ca salts of palm fatty acids (Ca-PFA) or unprocessed animal fat reduced DMI by dairy cows linearly, but the addition of long-chain fatty acids (LCFA) from hydrogenated fats (triacylglyerides or LCFA) had no significant $(P>0.50)$ effect on DMI. Data regarding the effects of fat supplementation on the concentration of available energy in the diet are more limited.

The NRC (2001) feed evaluation system estimates the $\mathrm{NE}_{\mathrm{L}}$ concentration of diets by first estimating the digestible energy (DE) concentration of feedstuffs (when fed at maintenance) from nutrient composition data. A discount factor is calculated from DMI and dietary total digestible nutrients (TDN) (at maintenance) concentration. An equation is used to convert discounted DE to metabolizable energy, and another equation is used to convert metabolizable energy to $\mathrm{NE}_{\mathrm{L}}$. The DE concentration of fat supplements is calculated 
as LCFA concentration multiplied by a digestibility coefficient derived from literature data times the average heat of combustion of LCFA (i.e., $9.4 \mathrm{Mcal} / \mathrm{kg}$ ). The accuracy of estimating $\mathrm{NE}_{\mathrm{L}}$ concentrations of diets with supplemental fat depends on the validity of the equations and on the accuracy of the mean LCFA digestibilities used by the NRC.

The primary objectives of this experiment concerned DE. Specific objectives were 1) to determine the effect of different fat supplements on dietary DE concentrations, 2) to calculate the DE concentration of 2 fat supplements, and 3) to compare estimated (NRC, 2001) dietary DE concentrations with measured values of diets containing 2 types of supplemental fat. A secondary objective was to determine the effects of feeding hydrogenated triacylglyercides from palm oil (HPO) on ruminal fermentation measures and production responses by dairy cows. One fat source (Ca-PFA) was used because the digestibility of its LCFA is well characterized. The other fat source (HPO) was used because no published data are available on the digestibility of its LCFA.

\section{MATERIALS AND METHODS}

\section{Cows and Diets}

Five rumen-cannulated Holstein cows (lactation $\geq 2$ ) at $66 \mathrm{DIM}(\mathrm{SD}=20)$ were used in a $5 \times 5$ Latin square experiment. Cows were fed 1 of 5 diets during each 28-d period of the experiment. One diet contained no supplemental fat, 2 diets contained $1.7 \%$ of DM as supplemental LCFA provided by Ca-PFA (Megalac; Church \& Dwight, Inc., Princeton, NJ) or by HPO (Hyprofat; Bonimex BV, Rotterdam, The Netherlands), and 2 diets contained $3.4 \%$ supplemental LCFA from CaPFA or HPO (Tables 1 and 2). The fat supplements differed in form (LCFA vs. triacylglyerides) and fatty acid profile (Table 3). Diets were similar in NDF, CP, metabolizable protein (NRC, 2001), and mineral and vitamin concentrations. Cows were housed in tie stalls during the experiment, fed a TMR for ad libitum consumption (ca. $5 \%$ orts) once daily, and milked $2 \times$ daily with milk weights recorded. On approximately d 21 ( \pm $2 \mathrm{~d}$ ) of each period, cows were moved to metabolism stalls for $4 \mathrm{~d}$. During that period, daily DMI, milk yield, and total fecal and urinary output were measured. Urine was collected via an externally attached urine cup (Fellner et al., 1988) into plastic vessels that contained adequate $\mathrm{HCl}$ to maintain urine $\mathrm{pH}<5$. Cows were weighed on $\mathrm{d} 1$ and 28 of each period.

\section{Sampling and Analyses}

Milk (a.m. and p.m.) was sampled $1 \mathrm{~d} /$ wk during the experiment and was sent to Ohio DHI Cooperative (Co- lumbus, $\mathrm{OH}$ ) for analysis of fat and true protein using a B2000 Infrared Analyzer (Bentley Instruments, Chaska, MN). Forages were sampled weekly for DM $\left(100^{\circ} \mathrm{C}\right.$ for $\left.24 \mathrm{~h}\right)$ to adjust TMR for changes in silage DM. During the total collection period, forages, concentrates, orts, milk, feces, and urine were sampled daily and composited by cow within period.

On approximately d 25 of each period, rumen fluid samples were taken via the rumen cannula at $0,3,6$, 9 , and $12 \mathrm{~h}$ post-feeding. The $\mathrm{pH}$ of rumen fluid samples was measured immediately after sampling. A sample of rumen fluid was acidified in 10\% phosphoric acid and then extracted for VFA and ammonia. The VFA were analyzed using GLC (Supelco, 1975) and ammonia using a urea method except that urease was excluded, and ammonium chloride rather than urea was used for the standard curve (Urea Nitrogen Procedure No. 640A; Sigma Diagnostics, St. Louis, MO). At 0 h, 9 nylon bags (ANKOM Technology, Fairport, NY) containing approximately $4 \mathrm{~g}$ of alfalfa hay (ground through a 1$\mathrm{mm}$ screen) were placed into the rumen of each cow. Three bags were removed from each cow after 12, 24, and $48 \mathrm{~h}$ of incubation. Bags were hand-washed in $37^{\circ} \mathrm{C}$ water until the water was clear, dried at $55^{\circ} \mathrm{C}$, and analyzed for NDF as described subsequently.

Feeds, orts, and feces were lyophilized, ground through a 1-mm screen (Wiley mill; Arthur H. Thomas, Philadelphia, PA), and analyzed for CP (AOAC, 1990), energy (Oxygen Bomb Calorimeter Model 1281; Parr Instruments, Moline, IL), LCFA, starch (Weiss and Wyatt, 2000) and NDF following Procedure A of Van Soest et al. (1991) except that an ANKOM 200 Fiber Analyzer (ANKOM Technology) was used. Long-chain fatty acids were assayed following the procedure of Sukhija and Palmquist (1988) except that $10 \%$ methanolic $\mathrm{HCl}$ was used rather than $5 \%$, and $10 \mathrm{~mL}$ of $6 \% \mathrm{~K}_{2} \mathrm{CO}_{3}$ was used rather than $5 \mathrm{~mL}$. Triacylglycerides from fecal samples from cows on select treatments were extracted for qualitative evaluation using TLC (Bilyk et al., 1991). Urine and milk sampled during the digestion trials were analyzed for N using Kjeldahl (AOAC, 1990).

\section{Calculations and Statistical Analyses}

Non-fiber carbohydrates (NFC) were calculated as $\mathrm{OM}$ - CP - NDF - LCFA (all values as a \% of DM). The TDN concentration was calculated as: digestible $\mathrm{CP}$ + digestible NDF + digestible NFC + (digestible LCFA $\times 2.25$ ). Digestibility of the LCFA provided by each supplemental fat was calculated using 2 different methods. The first method assumes that LCFA from basal ingredients in the treatment diets have the same digestibility as the control diet (Grummer, 1988). The 
Table 1. Ingredient composition of TMR (\% of DM) ${ }^{1}$

\begin{tabular}{|c|c|c|c|c|c|}
\hline \multirow[b]{2}{*}{ Ingredient } & \multirow[b]{2}{*}{ No fat } & \multicolumn{2}{|c|}{ Ca-PFA } & \multicolumn{2}{|c|}{ HPO } \\
\hline & & Low & High & Low & High \\
\hline Corn silage & 35.00 & 35.00 & 35.00 & 35.00 & 35.00 \\
\hline Alfalfa silage & 15.00 & 15.00 & 15.00 & 15.00 & 15.00 \\
\hline HPO & $\ldots$ & $\ldots$ & & 1.60 & 3.20 \\
\hline Ca-PFA & $\ldots$ & 1.75 & 3.50 & & \\
\hline Corn grain, ground & 24.20 & 22.89 & 21.75 & 22.62 & 21.07 \\
\hline Soybean meal, $44 \% \mathrm{CP}$ & 11.60 & 11.95 & 12.20 & 11.95 & 12.20 \\
\hline Soypass $^{2}$ & 5.60 & 5.30 & 5.00 & 5.30 & 5.00 \\
\hline Soybean hulls & 4.20 & 4.20 & 4.20 & 4.20 & 4.20 \\
\hline Wheat middlings & 1.80 & 1.80 & 1.80 & 1.80 & 1.80 \\
\hline Limestone & 1.00 & 0.56 & . & 0.90 & 0.90 \\
\hline Dicalcium phosphate & 0.27 & & & 0.30 & 0.30 \\
\hline Monosodium phosphate & $\ldots$ & 0.22 & 0.22 & & \\
\hline Sodium bicarbonate & 0.50 & 0.50 & 0.50 & 0.50 & 0.50 \\
\hline Trace mineral salt & 0.40 & 0.40 & 0.40 & 0.40 & 0.40 \\
\hline Magnesium oxide & 0.13 & 0.13 & 0.13 & 0.13 & 0.13 \\
\hline Trace minerals and vitamins ${ }^{3}$ & 0.30 & 0.30 & 0.30 & 0.30 & 0.30 \\
\hline
\end{tabular}

${ }^{1}$ Diets contained no supplemental fat or $1.7 \%$ (low) or $3.4 \%$ (high) fatty acids from Ca salts of palm fatty acids (Ca-PFA) or hydrogenated triacylglycerides from palm oil (HPO).

${ }^{2}$ Nonenzymatically browned soybean meal (Lignotech USA, Rothchild, WI).

${ }^{3}$ Contained $60.00 \%$ sodium selenate premix (200 mg/kg), $1.00 \%$ zinc oxide, $0.67 \%$ copper sulfate, and $38.30 \%$ vitamin premix. (Total diet contained $4500 \mathrm{IU}$ of supplemental vitamin A, 1500 IU of supplemental vitamin $\mathrm{D}$, and $22 \mathrm{IU}$ of supplemental vitamin E/ $\mathrm{kg}$ of DM.)

concentration of LCFA in the control diet (3.3\%) was subtracted from that in each supplemented diet to calculate the concentration of supplemental LCFA. Intake of basal and supplemental LCFA was calculated by multiplying the concentrations by DMI of each cow. Fecal output of undigested basal LCFA was estimated by multiplying intake of basal LCFA by the indigestibility coefficient of LCFA for the control cows. Fecal output of basal LCFA was subtracted from fecal output of LCFA when cows were fed the supplemented diets. Digestibility of supplemental LCFA was calculated as intake of supplemental LCFA minus fecal output of supplemental LCFA divided by intake of supplemental LCFA. These values more closely reflect true digestibility rather than apparent digestibility because endogenous fecal LCFA would be included in the indigestible basal fraction. The second method used to calculate digestibility was to regress intakes of apparently digestible LCFA on intakes of LCFA (i.e., a Lucas test; Van Soest, 1982) within fat source (data from the control diet were included in both fat source regressions), and the slope is an estimate of true digestibility. Estimating the DE concentration of the supplements is more difficult because the supplemental fat provided only a small fraction $(<10 \%)$ of the total GE in the diets. In comparison, the fat supplements provided up to approximately $50 \%$ of the LCFA in the diets. The DE of the fat supplements was calculated using treatment means and by assuming the corn grain that was replaced by the fat supplements contained $3.75 \mathrm{Mcal} / \mathrm{kg}$ of DE (NRC, 2001). The DE of

Table 2. Nutrient composition of TMR (DM basis). ${ }^{1}$

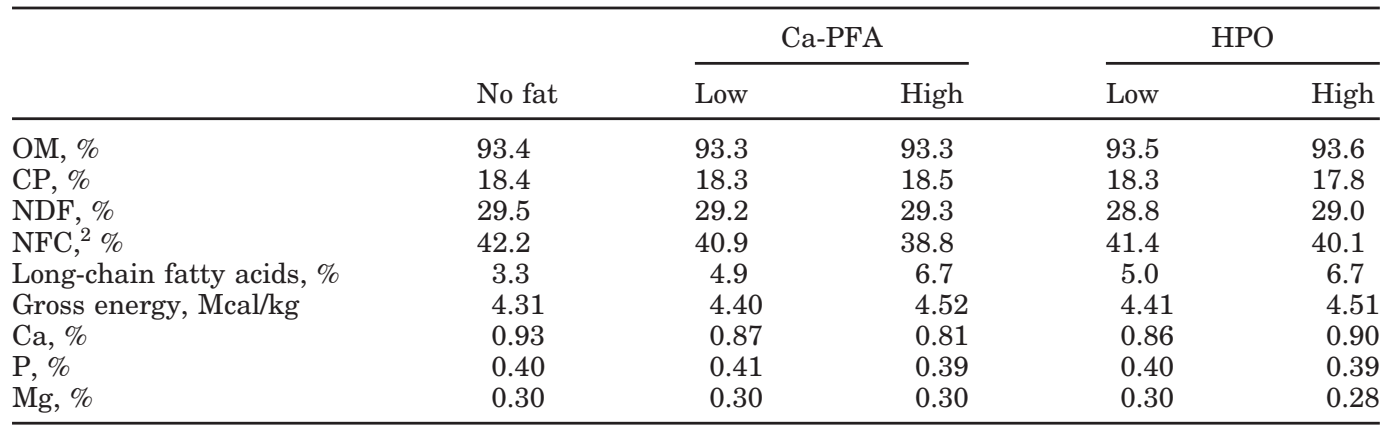

${ }^{1}$ Diets contained no supplemental fat or $1.7 \%$ (low) or $3.4 \%$ (high) fatty acids from Ca salts of palm fatty acids (Ca-PFA) or hydrogenated triacylglycerides from palm oil (HPO).

${ }^{2} \mathrm{NFC}=$ non-fiber carbohydrates $(\mathrm{OM}-\mathrm{NDF}-\mathrm{CP}-$ long-chain fatty acids $)$. 
Table 3. Fatty acid and energy concentrations of the fat supplements. ${ }^{1}$

\begin{tabular}{lcc}
\hline & Ca-PFA & HPO \\
\hline Gross energy, Mcal/kg & 8.08 & 9.39 \\
Total fatty acids, \% of DM & 83.3 & 94.3 \\
Fatty acid, ${ }^{2} \%$ of total fatty acids & & \\
14:0 & 1.4 & 1.3 \\
$16: 0$ & 47.5 & 59.1 \\
$18: 0$ & 4.1 & 31.3 \\
cis-9 18:1 & 35.5 & 5.8 \\
$18: 2$ & 8.1 & 1.2 \\
Other & 3.4 & 1.3 \\
Calculated iodine value & 3 \\
\hline
\end{tabular}

\footnotetext{
${ }^{1}$ Supplements were Ca salts of palm fatty acids (Ca-PFA) or hydrogenated triacylglycerides from palm oil (HPO).

${ }^{2}$ Number of carbons:number of double bonds. Fatty acids comprising $<1 \%$ of total fatty acids are included in the 'other' category.

${ }^{3}$ Calculated from fatty acid composition (AOCS, 1989).
}

the fat supplements within each diet was calculated by difference.

Data for each cow-period were entered into the NRC (2001) model to obtain estimates of dietary concentrations of undiscounted TDN, discounted $\mathrm{DE}$, and $\mathrm{NE}_{\mathrm{L}}$, and $\mathrm{NE}_{\mathrm{L}}$ balance. Actual feed composition data were used when available (i.e., $\mathrm{CP}, \mathrm{NDF}$, ash, and LCFA); otherwise, library values were used. The NRC value for LCFA digestibility for Ca-PFA was used (i.e., 0.86) so that the evaluation would be totally independent of the data from this experiment. Data were not available on the digestibility of HPO; therefore, the digestibility of HPO determined in this experiment was used.

Production data (milk yield and composition and DMI) during the last $2 \mathrm{wk}$ of each period were averaged within cow-period. The production data, average BW (d-1 and d-28 weights), calculated energy data, and apparent digestibility coefficients were analyzed using Proc MIXED (SAS, 1999). The model included cow (random, $4 \mathrm{df}$ ), period (fixed, $4 \mathrm{df}$ ), treatment (fixed, $4 \mathrm{df}$ ), and error (12 df). Treatment effects were partitioned into 4 orthogonal contrasts: 1 ) effect of fat supplementation (control diet vs. all other diets), 2) effect of type of fat supplement (diets with Ca-PFA vs. diets with HPO), 3) effect of amount of fat supplement (diets with $1.7 \%$ supplemental LCFA vs. diets with $3.4 \%$ supplemental fat), and 4) interaction between fat source and amount. Measured DE concentrations were compared to NRC estimated concentrations using Proc MIXED. The model was the same as previously mentioned except that method (measured or estimated) and method by treatment interaction were included as fixed effects.

The rumen data and in situ NDF digestibility were analyzed using Proc MIXED with the model described previously except that time as a repeated measure (fixed, $4 \mathrm{df}$ for rumen measures and $2 \mathrm{df}$ for in situ data) and the time by treatment interaction (fixed, 16 $\mathrm{df}$ for rumen and $8 \mathrm{df}$ for in situ) were included in the model. Proc REG of SAS was used to perform the Lucas test.

\section{RESULTS AND DISCUSSION}

\section{Nutrient Digestibility}

Cows fed the diets with Ca-PFA had lower $(P<0.05)$ DMI than cows fed HPO (Table 4), but this difference was caused mainly by the diet with $3.5 \%$ Ca-PFA (fat source by amount interaction, $P<0.05$ ). The DMI of cows fed the $3.5 \%$ Ca-PFA diet was about $5 \%$ lower than the DMI of cows fed the control diet. That difference was less than the mean depression calculated by Allen (2000) for Ca-PFA but was within the 95\% confidence interval. Intake by cows fed HPO was equal to or higher than that by cows fed the control diet. Source of fat affected nutrient digestibility more than rate of supplementation (Table 4). Differences among treatments were much larger for LCFA digestibility than for any other nutrient. The higher $(P<0.01)$ LCFA digestibility for Ca-PFA diets vs. HPO diets quantitatively accounted for the higher $(P<0.05) \mathrm{DM}, \mathrm{OM}$, and energy digestibility observed with those diets. The lower LCFA digestibilities for diets containing HPO are most likely functions of the LCFA profile. Saturated fats are usually less digestible than unsaturated fats (Firkins and Eastridge, 1994), and the HPO was much more saturated (iodine value of 7 vs. 47) than the Ca-PFA. With saturated fats (iodine value $<12$ ), digestibility of LCFA from free fatty acids was higher than that from triacylglyerides (Elliott et al., 1999). Fatty acids with $16 \mathrm{C}$ are usually more digestible than LCFA with $18 \mathrm{C}$ (Weisbjerg et al., 1992), and although the HPO had a higher C 16:C18 ratio than Ca-PFA (1.54 vs. 1.00), the increased proportion of C 16 fatty acids in the HPO did not overcome the negative effects of saturation, fat structure, or both on LCFA digestibility.

Cows fed HPO had lower NDF digestibility than cows fed Ca-PFA. The lower NDF digestibility for cows fed HPO could have been caused by alterations within the rumen; however, no effects of fat source were found on VFA concentrations or profile or on in situ digestibility (Table 5), suggesting that fat source had minimal effects on ruminal fermentation. A likely reason for the fat source effects on NDF digestibility is a differencce in DMI. Cows fed HPO had higher DMI than cows fed CaPFA, and digestibility of NDF can be reduced when DMI is increased (Colucci et al., 1989). No treatment effects were observed for starch digestibility.

Nitrogen metabolism was not influenced greatly by treatment. Cows fed HPO consumed more N $(P<0.05)$ than cows fed Ca-PFA because of higher DMI (Table 6). 
Table 4. Effect of supplemental fat on nutrient digestibility. ${ }^{1}$

\begin{tabular}{|c|c|c|c|c|c|c|c|}
\hline & \multirow[b]{2}{*}{ No fat } & \multicolumn{2}{|c|}{ Ca-PFA } & \multicolumn{2}{|c|}{$\mathrm{HPO}$} & \multirow[b]{2}{*}{$\mathrm{SE}$} & \multirow[b]{2}{*}{ Contrast $^{2}$} \\
\hline & & Low & High & Low & High & & \\
\hline DMI, kg/d & 23.0 & 23.1 & 21.9 & 23.6 & 24.1 & 0.7 & 2,4 \\
\hline Wet feces, kg/d & 46.4 & 44.5 & 40.6 & 48.0 & 46.7 & 1.8 & 2,3 \\
\hline Urine, $\mathrm{kg} / \mathrm{d}$ & 23.3 & 25.4 & 23.1 & 24.1 & 24.9 & 2.0 & NS \\
\hline \multicolumn{8}{|c|}{ Digestibility coefficients } \\
\hline DM, \% & 69.9 & 69.0 & 69.9 & 68.2 & 67.6 & 0.6 & 2 \\
\hline $\mathrm{OM}, \%$ & 70.0 & 69.8 & 70.9 & 69.2 & 69.5 & 0.6 & 2 \\
\hline NDF, $\%$ & 53.1 & 52.8 & 53.6 & 51.7 & 47.3 & 1.6 & 2 \\
\hline Starch, \% & 90.2 & 89.8 & 90.5 & 89.0 & 89.0 & 1.0 & NS \\
\hline $\mathrm{CP}, \%$ & 65.9 & 66.8 & 68.6 & 66.8 & 67.1 & 1.1 & NS \\
\hline Fatty acids, \% & 73.7 & 80.2 & 80.9 & 61.7 & 54.8 & 2.0 & $1,2,4^{*}$ \\
\hline Energy, \% & 68.8 & 69.0 & 70.0 & 67.4 & 65.3 & 0.8 & $2,4^{*}$ \\
\hline
\end{tabular}

${ }^{1}$ Diets contained no supplemental fat or $1.7 \%$ (low) or $3.4 \%$ (high) fatty acids from Ca salts of palm fatty acids (Ca-PFA) or hydrogenated triacylglycerides from palm oil (HPO).

${ }^{2}$ Contrasts $(P<0.05$, except $* P<0.10)$ : $1=$ control vs. fat, $2=$ source $($ Ca-PFA vs. HPO), $3=$ rate (low vs. high), and $4=$ source $\times$ rate interaction. NS $=P>0.10$.

Table 5. Effect of supplemental fat on rumen measures (averaged over 0, 3, 6, 9, and $12 \mathrm{~h}$ post-feeding). ${ }^{1,2}$

\begin{tabular}{|c|c|c|c|c|c|c|}
\hline & \multirow[b]{2}{*}{ No fat } & \multicolumn{2}{|c|}{ Ca-PFA } & \multicolumn{2}{|c|}{$\mathrm{HPO}$} & \multirow[b]{2}{*}{$\mathrm{SE}$} \\
\hline & & Low & High & Low & High & \\
\hline $\mathrm{pH}$ & 5.81 & 5.87 & 5.86 & 5.82 & 5.81 & 0.05 \\
\hline $\mathrm{NH}_{3} \mathrm{~N}, \mathrm{mg} / \mathrm{dL}$ & 5.01 & 4.80 & 4.53 & 4.66 & 4.57 & 0.42 \\
\hline Total VFA, mmol/L & 115 & 114 & 114 & 115 & 113 & 3 \\
\hline \multicolumn{7}{|c|}{ VFA (mmol/100 mmol total VFA) } \\
\hline Acetate & 58.5 & 58.6 & 58.4 & 57.5 & 57.6 & 1.1 \\
\hline Propionate & 22.3 & 22.9 & 23.0 & 24.1 & 23.4 & 1.4 \\
\hline Butyrate & 14.9 & 14.0 & 14.1 & 13.9 & 14.6 & 0.6 \\
\hline Isobutyrate $^{3}$ & 0.79 & 0.82 & 0.87 & 0.79 & 0.73 & 0.04 \\
\hline Valerate $^{4}$ & 2.03 & 2.25 & 2.25 & 2.33 & 2.20 & 0.13 \\
\hline Isovalerate & 1.45 & 1.41 & 1.47 & 1.37 & 1.46 & 0.13 \\
\hline \multicolumn{7}{|c|}{ In situ NDF disappearance, ${ }^{5} \%$} \\
\hline $12 \mathrm{~h}$ & 27.4 & 26.0 & 23.7 & 23.5 & 23.4 & 2.4 \\
\hline $24 \mathrm{~h}$ & 37.3 & 38.2 & 38.7 & 36.1 & 34.2 & 3.3 \\
\hline $48 \mathrm{~h}$ & 51.8 & 53.4 & 51.6 & 49.5 & 52.1 & 2.5 \\
\hline
\end{tabular}

${ }^{1}$ Diets contained no supplemental fat or $1.7 \%$ (low) or $3.4 \%$ (high) fatty acids from Ca salts of palm fatty acids (Ca-PFA) or hydrogenated triacylglycerides from palm oil (HPO).

${ }^{2}$ No treatment by time interactions $(P>0.15)$.

${ }^{3}$ Source $(\mathrm{Ca}-\mathrm{PFA}$ vs. HPO) effect $(P<0.05)$.

${ }^{4}$ Control vs. fat-supplemented $\operatorname{differ}(P<0.05)$.

${ }^{5}$ From alfalfa hay.

Table 6. Effect of fat supplementation on $\mathrm{N}$ excretion and balance. ${ }^{1}$

\begin{tabular}{|c|c|c|c|c|c|c|c|}
\hline & \multirow[b]{2}{*}{ No fat } & \multicolumn{2}{|c|}{ Ca-PFA } & \multicolumn{2}{|c|}{ HPO } & \multirow[b]{2}{*}{$\mathrm{SE}$} & \multirow[b]{2}{*}{ Contrast $^{2}$} \\
\hline & & Low & High & Low & High & & \\
\hline & & & $-(\% \mathrm{c}$ & ke) & & - & \\
\hline Intake, $\mathrm{g} / \mathrm{d}$ & 681 & 680 & 650 & 693 & 692 & 222 & \\
\hline Fecal & 34.1 & 33.2 & 31.4 & 33.2 & 32.8 & 1.1 & $2^{*}$ \\
\hline Urinary & 29.4 & 30.8 & 31.8 & 29.4 & 29.1 & 1.1 & 2 \\
\hline Milk & 30.5 & 30.2 & 31.3 & 31.2 & 31.7 & 1.3 & NS \\
\hline Retained & 5.9 & 5.9 & 5.5 & 6.2 & 6.4 & 1.3 & NS \\
\hline
\end{tabular}

${ }^{1}$ Diets contained no supplemental fat or $1.7 \%$ (low) or $3.4 \%$ (high) fatty acids from Ca salts of palm fatty acids (Ca-PFA) or hydrogenated triacylglycerides from palm oil (HPO).

${ }^{2}$ Contrasts $(P<0.05$, except $* P<0.10)$ : $1=$ control vs. fat, $2=$ source $($ Ca-PFA vs. HPO), $3=$ rate (low vs. high), and $4=$ source $\times$ rate interaction. NS $=P>0.10$. 
Table 7. Calculated digestibility of long-chain fatty acids (LCFA) and digestible energy (DE) concentrations of the fat supplements. ${ }^{1}$

\begin{tabular}{|c|c|c|c|c|}
\hline & \multicolumn{2}{|c|}{ Ca-PFA } & \multicolumn{2}{|c|}{ HPO } \\
\hline & Low & High & Low & High \\
\hline LCFA digestibility, ${ }^{2} \%$ & $92.9(3.1)^{3}$ & $87.5(1.9)$ & $39.0(3.8)$ & $38.1(2.9)$ \\
\hline $\mathrm{DE},{ }^{4} \mathrm{Mcal} / \mathrm{kg}$ & 7.1 & 7.6 & 3.7 & 3.1 \\
\hline \multicolumn{5}{|c|}{$\begin{array}{l}{ }^{1} \text { Diets contained no supplemental fat or } 1.7 \% \text { (low) or } 3.4 \% \text { (high) fatty acids from Ca salts of palm fatty } \\
\text { acids (Ca-PFA) or hydrogenated triacylglycerides from palm oil (HPO). }\end{array}$} \\
\hline \multicolumn{5}{|c|}{$\begin{array}{l}{ }^{2} \text { Calculated as }\{[\mathrm{DMI} \times(\% \text { total fatty acids }-\% \text { fatty acids in control diet })]-(\text { total fecal fatty acids }- \\
\text { indigestible fatty acids from basal ingredients })\} / \text { intake of fatty acids from supplement. Indigestible fatty acids } \\
\text { from basal ingredients were calculated by multiplying intake of basal fatty acids by average indigestibility of } \\
\text { fatty acids when cows were fed the control diet. }\end{array}$} \\
\hline \multicolumn{5}{|c|}{${ }^{3}$ Values in parentheses are standard errors. } \\
\hline \multicolumn{5}{|c|}{$\begin{array}{l}{ }^{4} \text { Calculated by assuming a DE content of corn grain replaced by the fat supplement was } 3.75 \mathrm{Mcal} / \mathrm{kg} \\
\text { (NRC, 2001). Treatment means, not individual cow data, were used in the calculations; therefore, no measure } \\
\text { of dispersion could be calculated. }\end{array}$} \\
\hline
\end{tabular}

Cows fed HPO excreted slightly less $(P<0.05)$ urinary N (as a percentage of $\mathrm{N}$ intake) than cows fed Ca-PFA; however, no differences among treatments were observed in the mass of $\mathrm{N}$ excreted in the urine (data not shown). The mass of $\mathrm{N}$ excreted in milk was higher $(P<0.05)$ for cows fed HPO (data not shown), but no differences were observed when expressed as a percentage of $\mathrm{N}$ intake.

The digestibility of the LCFA provided by the supplements calculated using regression analysis and by difference was similar within fat source and averaged 89 and $38 \%$ for the Ca-PFA and HPO, respectively (Table 7; Figure 1). The LCFA digestibility for Ca-PFA obtained in this study was essentially equal to the mean value of $86 \%$ (SD = 11) obtained by NRC (2001). Direct comparable data for HPO are not available. Elliott et al. (1996) reported that the digestibility of palm LCFA (not triacylglyerides) was 58\%, which was equal to $77 \%$ of the value those researchers measured for Ca-PFA. In our study, digestibility of LCFA from HPO was $43 \%$ of the value measured for Ca-PFA. The palm oil product in the Elliott et al. (1996) study and the product used in this study had similar calculated iodine values, but the product in the Elliott et al. study had a lower C 16:C18 ratio than HPO (1.13 vs. 1.54). Esterification could account for part of the difference between the digestibility of HPO in this study and that of palm oil LCFA in the Elliott et al. study. In beef steers, digestibility of triacylglyerides provided by hydrogenated tallow (calculated by difference) was $31 \%$ compared with $85 \%$ for the control diet (no added fat) (Elliott et al., 1999). Triacylglyeride digestibility was not measured in our study; however, the presence of triacylglycerides in fecal samples from cows fed the high rate of $\mathrm{Ca}$ $\mathrm{PFA}$, the high rate of $\mathrm{HPO}$, and the control diet was monitored using TLC. No spot corresponding to triacylglyerides was observed in fecal samples from cows fed control or Ca-PFA, but a large spot was observed in samples from all cows fed HPO. This observation plus the data of Elliott et al. (1999) are strongly suggestive that lipolysis limits fatty acid digestibility of saturated triacylglycerides.

\section{Energy}

The available energy concentrations expressed as DE (Mcal/kg of DM) and TDN (\% of DM) were higher in fat-supplemented diets than in the control diet $(P<$ $0.05)$ and increased as fat supplementation rate increased $(P<0.05)$. However, those differences were caused by Ca-PFA (Table 8). The concentration of DE and TDN in diets with Ca-PFA increased with increasing supplementation, but no changes were observed in diets with HPO. The calculated DE concentrations averaged 7.3 Mcal/kg for Ca-PFA and $3.4 \mathrm{Mcal} / \mathrm{kg}$ for HPO (Table 7). The DE value of Ca-PFA is within the range of previously measured values (Andrew et al., 1991; Elliott et al., 1996; Aldrich et al., 1997). The only significant effect observed for intake of DE or TDN was control vs. fat-supplemented diets. Cows fed diets with supplemental fat consumed on average $1.2 \mathrm{Mcal} / \mathrm{d}$ more $\mathrm{DE}(P<0.05)$ than cows fed the unsupplemented diet. The reduced DMI when cows were fed Ca-PFA negated the improved energy digestibility of diets with Ca-PFA so that no difference in DE (or TDN) intake was observed between fat sources. The lack of a difference in DE intake between fat sources could mean that DMI of the fat supplemented diets was regulated by supply of metabolic fuel (i.e., energy). Intake of digestible fatty acids was much higher for cows fed Ca-PFA than for cows fed HPO $(P<0.01$; data not shown), suggesting that the mass of total fatty acids absorbed from the gut was not regulating DMI across fat sources. However, it could be regulating DMI within the Ca-PFA treat- 


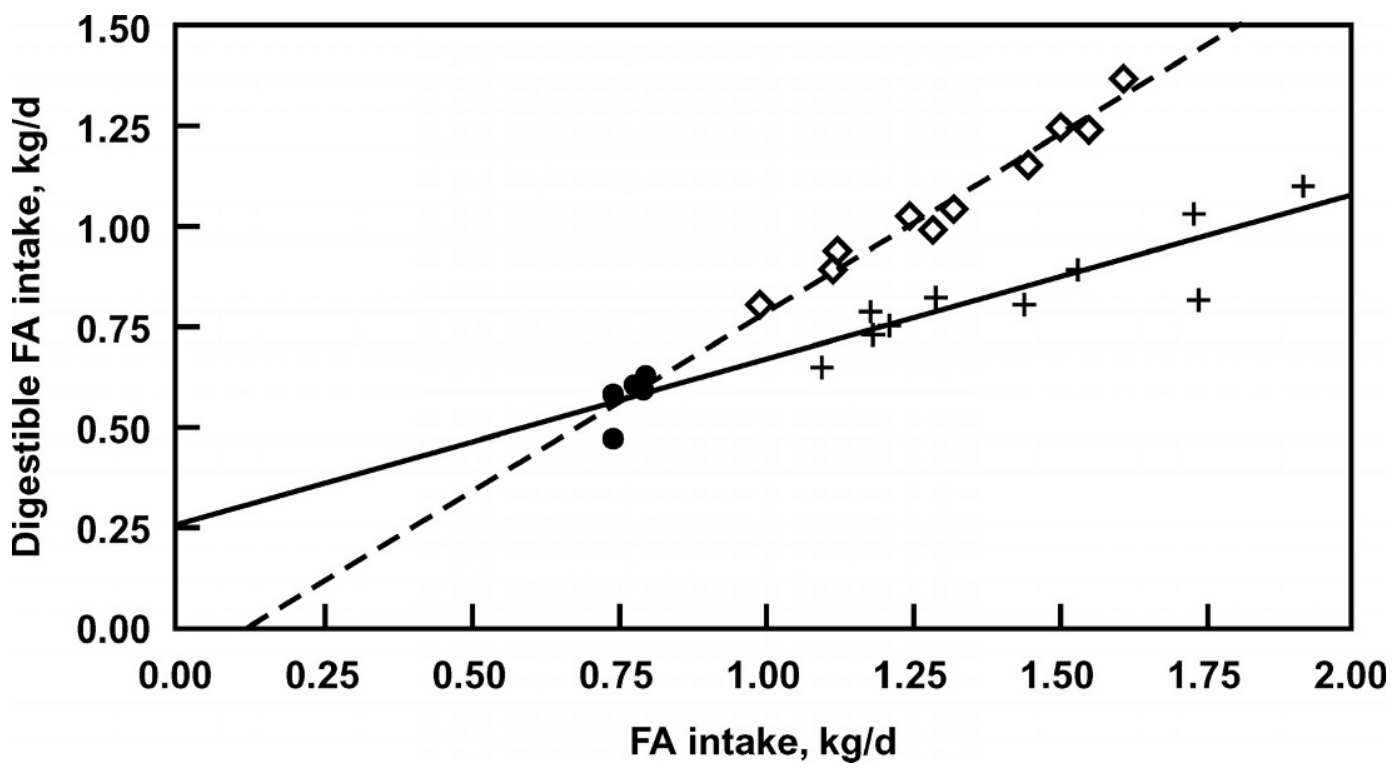

Figure 1. Lucas test for fatty acids (FA) from Ca salts of palm FA (Ca-PFA) or hydrogenated triacylglycerides from palm oil (HPO). The control diet $(\bullet)$ contained no supplemental fat and was included in both regressions. For Ca-PFA $(--\diamond--)$, Y $=0.89 \mathrm{X}-0.11$; for HPO $(-+-), \mathrm{Y}=0.41 \mathrm{X}+0.41$. The SE associated with the slopes (estimate of true digestibility of long-chain FA from the supplement) were 0.04 and 0.04 for Ca-PFA and HPO, respectively.

ments. Absorption of a specific fatty acid could be involved with DMI regulation, but this was not measured in this experiment.

The measured concentration of $\mathrm{DE}$ in the diets did not differ $(P>0.35)$ from concentrations estimated using NRC (2001) equations (Table 8). For each diet, mean estimated and mean measured DE concentrations were within $1 \%$ of each other. In addition, the same treatment effects were observed for both measured and estimated values. The digestibility data for the control and
Ca-PFA diets were not used in the NRC estimation; however, the LCFA digestibility for HPO measured in this experiment (Table 7) had to be used in the NRC equations for the $2 \mathrm{HPO}$ diets, which means that estimated and measured DE values for those 2 diets are not totally independent. The NRC model did not accurately estimate TDN concentrations. As expected, estimated TDN concentrations (at maintenance) were higher than measured values because of the effect intake has on digestibility (Tyrrell and Moe, 1975), but after adjusting

Table 8. Effect of supplemental fat on energy utilization. ${ }^{1}$

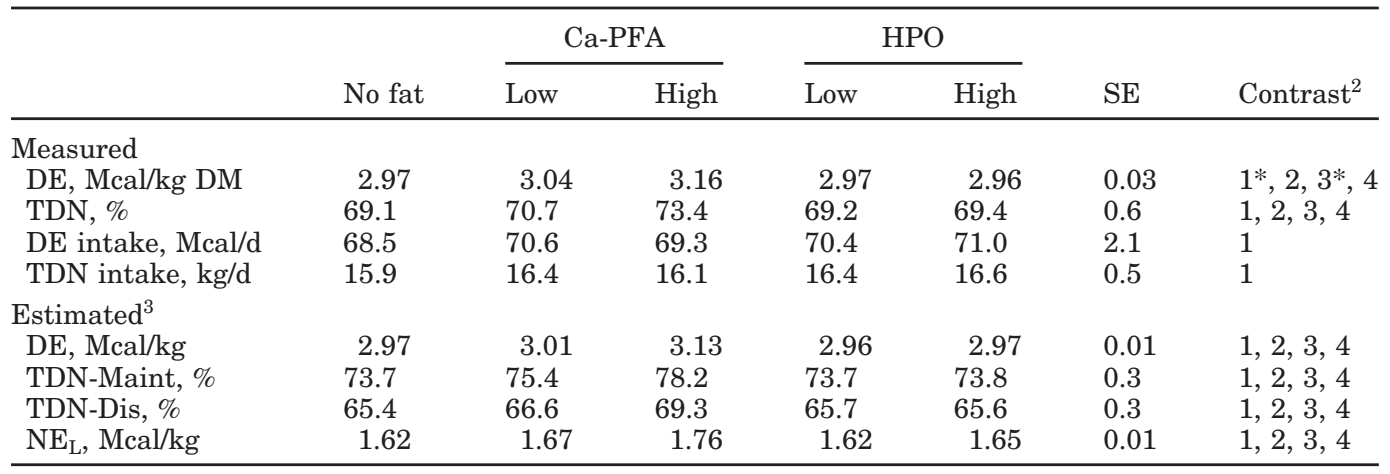

${ }^{1}$ Diets contained no supplemental fat or $1.7 \%$ (low) or $3.4 \%$ (high) fatty acids from Ca salts of palm fatty acids (Ca-PFA) or hydrogenated triacylglycerides from palm oil (HPO). DE = digestible energy, TDN-Maint = TDN (total digestible nutrients) calculated at maintenance level of intake, and TDN-Dis = TDN discounted for actual DMI.

${ }^{2}$ Contrasts $(P<0.05$, except $* P<0.10): 1=$ control vs. fat, $2=$ source $($ Ca-PFA vs. HPO), $3=$ rate (low vs. high), and $4=$ source $\times$ rate interaction. NS $=P>0.10$.

${ }^{3}$ Calculated from NRC (2001). 
Table 9. Effect of supplemental fat on production measures (data from last 2 wk of each period).

\begin{tabular}{lcccccccc}
\hline & & \multicolumn{2}{c}{ Ca-PFA } & & \multicolumn{2}{c}{ HPO } & & \\
\cline { 3 - 4 } & No fat & Low & High & & Low & High & SE & Contrast $^{2}$ \\
\hline DMI, kg/d & 23.1 & 23.2 & 21.9 & & 23.7 & 24.0 & 0.7 & $2,3,4$ \\
BW, kg & 633 & 636 & 622 & & 632 & 631 & 21 & NS \\
BW change, kg/d & 0.36 & 0.24 & 0.08 & & 0.21 & 0.03 & 0.17 & NS \\
Milk, kg/d & 38.0 & 41.5 & 43.6 & & 41.1 & 39.3 & 2.9 & $1,2,4$ \\
$4 \%$ FCM, kg/d & 38.7 & 43.2 & 45.0 & & 40.9 & 43.5 & 3.2 & $1,3^{*}$ \\
Fat, \% & 4.18 & 4.31 & 4.18 & & 3.98 & 4.67 & 0.25 & $3^{*}, 4$ \\
Fat, kg/d & 1.57 & 1.78 & 1.84 & & 1.63 & 1.85 & 0.15 & $1,3^{*}$ \\
Protein, \% & 3.07 & 3.00 & 2.82 & & 2.99 & 3.03 & 0.13 & $1,2,3^{*}, 4$ \\
Protein, kg/d & 1.15 & 1.22 & 1.21 & & 1.22 & 1.18 & 0.06 & $1^{*}$ \\
\hline
\end{tabular}

${ }^{1}$ Diets contained no supplemental fat or $1.7 \%$ (low) or $3.4 \%$ (high) fatty acids from Ca salts of palm fatty acids (Ca-PFA) or hydrogenated triacylglycerides from palm oil (HPO).

${ }^{2}$ Contrasts $(P<0.05$. except $* P<0.10): 1=$ control vs. fat, $2=$ source $($ Ca-PFA vs. HPO), $3=$ rate (low vs. high), and $4=$ source $\times$ rate interaction. NS $=P>0.10$.

TDN concentrations for intake (NRC discount factor), estimated TDN values were lower $(P<0.05)$ than measured values. The NRC (2001) equations either underestimated TDN concentration (at maintenance), overestimated the discount factor, or both. In the NRC (2001) model, TDN is used to calculate the discount factor, but is not used to directly calculate DE.

Energy balance (energy intake minus energy requirements) is a more comprehensive evaluation of energy systems than comparing only concentrations of $\mathrm{DE}$ in diets. The only direct measure of energy balance available in this experiment was change in BW. Accuracy and precision of measured BW change in a Latin square experiment is suspect because of limited measurements, the short duration of periods, residual effects, and transient changes in gut fill caused by changes in DMI among treatments. Change in BW was not affected by treatment (Table 9) and averaged $0.18 \mathrm{~kg} / \mathrm{d}$ across all treatments. Assuming BW gain required $5 \mathrm{Mcal}$ of $\mathrm{NE}_{\mathrm{L}} / \mathrm{kg}$ (NRC, 2001) and that $\mathrm{BW}$ gain reflects tissue retention of energy and not changes in gut fill and body water, average $\mathrm{NE}_{\mathrm{L}}$ balance calculated from $\mathrm{BW}$ change was $0.9 \mathrm{Mcal} / \mathrm{d}$ (i.e., $0.18 \mathrm{~kg} / \mathrm{d} \times 5 \mathrm{Mcal} / \mathrm{kg}$ ). The mean $\mathrm{NE}_{\mathrm{L}}$ balance calculated using $\mathrm{NRC}$ (2001) was -2.0 $\mathrm{Mcal} / \mathrm{d}$. The disparity between the $\mathrm{NE}_{\mathrm{L}}$ balance calculated from BW change and that calculated using NRC equations was $2.9 \mathrm{Mcal} / \mathrm{d}$ or about $7 \%$ of the $\mathrm{NE}_{\mathrm{L}}$ requirement calculated by NRC. Assuming the measured BW change was accurate, the NRC (2001) overestimated $\mathrm{NE}_{\mathrm{L}}$ requirements for maintenance or milk production, underestimated the $\mathrm{NE}_{\mathrm{L}}$ concentration in the diets, or both. If an error is occurring in estimating feed $\mathrm{NE}_{\mathrm{L}}$, it must be in the conversion of $\mathrm{DE}$ to $\mathrm{NE}_{\mathrm{L}}$ because DE concentrations were accurately estimated using NRC (2001). Long-term, continuous lactation studies are needed to obtain better comparisons between actual and NRC-estimated $\mathrm{NE}_{\mathrm{L}}$ balance.

\section{Production Measures}

Many production responses in this short-term experiment were affected by fat source, supplementation rate, and the source by rate interaction (Table 9). Production responses to Ca-PFA were in agreement with most previous research that used higher producing cows (Schauff and Clark, 1992; Moallem et al., 2000). Treatment effects on DMI were similar to those observed during the collection phase of the experiment (Table 4). The lower DMI for cows fed Ca-PFA compared with those fed HPO could have been caused by palatability differences, differences in energy digestibility (i.e., cows fed Ca-PFA were able to consume the same quantity of DE as cows fed PFO at a lower DMI), or chemical form of the LCFA (fatty acid salts vs. triacylglyerides). A summary of literature data suggested that free fatty acids have a greater negative effect on DMI than do triacylglycerides (Benson et al., 2001). Yields of milk, FCM, milk fat, and milk protein were higher when cows were fed supplemental fat $(P<0.05)$. Cows fed Ca-PFA produced more milk with a lower percentage of milk protein than did cows fed HPO, but the milk protein response was largely caused by the high Ca-PFA diet (fat source by rate interaction; $P<0.05$ ). Increased fat supplementation increased yields of FCM and milk fat. The increased yield of milk and components with supplemental fat was much higher than would be estimated (NRC, 1989) from the increase in DE intake (Table 8). Fat supplementation increased yield of FCM by about $4 \mathrm{~kg} / \mathrm{d}$, but DE intake was only about $2 \mathrm{Mcal} /$ $\mathrm{d}$ higher (enough DE to support approximately $1.4 \mathrm{~kg}$ of FCM [NRC, 1989]). The disparity between change in FCM yield and change in DE intake caused by treatments was greater at the higher supplementation rate. Part of the disparity was caused by source of DE. The conversion of $\mathrm{DE}$ to $\mathrm{NE}_{\mathrm{L}}$ from fat is more efficient than the conversion of DE from carbohydrate (Andrew et al., 
1991). In the control diet, $7.9 \%$ of the $\mathrm{DE}$ was derived from digested LCFA compared with 12.5 and $16.6 \%$ for the low and high Ca-PFA diets and 10.0 and $11.6 \%$ for the low and high HPO diets.

\section{CONCLUSIONS}

In agreement with previous research, the digestibility of LCFA from Ca-PFA is high and increases the concentration of DE in diets. Supplementing diets with Ca-PFA increased DE intake, but because of negative effects on DMI, the relative increase was less than that for $\mathrm{DE}$ concentration. The digestibility of LCFA from HPO was low and did not increase the DE concentration in diets. However, small increases in DMI when HPO was supplemented caused DE intake to increase compared with the unsupplemented diet. The NRC (2001) model accurately estimated DE concentrations of all diets; however, limited evidence suggests that it underestimated energy balance.

\section{REFERENCES}

Aldrich, C. G., N. R. Merchen, J. K. Drackley, G. C. Fahey, Jr., and L. L. Berger. 1997. The effects of chemical treatment of whole canola seed on intake, nutrient digestibilities, milk production, and milk fatty acids of Holstein cows. J. Anim. Sci. 75:512-521.

Allen, M. S. 2000. Effects of diet on short-term regulation of feed intake by lactating dairy cows. J. Dairy Sci. 83:1598-1624.

AOCS. 1989. Official Methods and Recommended Practices. 4th ed. Am. Oil Chem. Soc., Champaign, IL.

Andrew, S. M., H. F. Tyrrell, C. K. Reynolds, and R. A. Erdman. 1991. Net energy for lactation of calcium salts of long-chain fatty acids for cows fed silage-based diets. J. Dairy Sci. 74:2588-2600.

Association of Official Analytical Chemists. 1990. Official Methods of Analysis. Vol. I. 15th ed. AOAC, Arlington, VA.

Benson, J. A., C. K. Reynolds, D. J. Humphries, S. M. Rutter, and D. E. Beever. 2001. Effects of abomasal infusion of long-chain fatty acids on intake, feeding behavior and milk production in dairy cows. J. Dairy Sci. 84:1182-1191.

Bilyk, A., G. J. Piazza, R. G. Bistline, Jr., and M. J. Haas. 1991. Separation of cholesterol, and fatty acylglycerols, acids and amides by thin-layer chromatography. Lipids 26:405-406.

Colucci, P. E., G. K. Macleod, W. L. Grovum, L. W. Cahill, and I. McMillan. 1989. Comparative digestion in sheep and cattle fed different forage to concentrate ratios at high and low intakes. J. Dairy Sci. 72:1774-1785.

Elliott, J. P., J. K. Drackley, A. D. Beaulieu, C. G. Aldrich, and N. R. Merchen. 1999. Effects of saturation and esterification of fat sources on site and extent of digestion in steers: Digestion of fatty acids, triglycerides, and energy. J. Anim. Sci. 77:1919-1929.

Elliott, J. P., J. K. Drackley, and D. J. Weigel. 1996. Digestibility and effects of hydrogenated palm fatty acid distillate in lactating dairy cows. J. Dairy Sci. 79:1031-1039.

Fellner, V., M. F. Weiss, A. T. Belo, R. L. Belyea, F. A. Martz, and A. H. Orma. 1988. Urine cup for collection of urine from cows. J. Dairy Sci. 71:2250-2255.

Firkins, J. L., and M. L. Eastridge. 1994. Assessment of the effects of iodine value on fatty acid digestibility, feed intake, and milk production. J. Dairy Sci. 77:2357-2366.

Grummer, R. R. 1988. Influence of prilled fat and calcium salts of palm oil fatty acids on ruminant fermentation and nutrient digestibility. J. Dairy Sci. 71:117-123.

Kellogg, D. W., J. A. Pennington, Z. B. Johnson, and R. Panivivat. 2001. Survey of management practices used for the highest producing DHI herds in the United States. J. Dairy Sci. 84 (E Suppl.):E120-E127.

Moallem, U., Y. Folman, and D. Sklan. 2000. Effects of somatotropin and dietary calcium soaps of fatty acids in early lactation on milk production, dry matter intake, and energy balance of highyielding dairy cows. J. Dairy Sci. 83:2085-2094.

National Research Council. 1989. Nutrient Requirements for Dairy Cattle. 6th rev. ed. Natl. Acad. Sci., Washington, DC.

National Research Council. 2001. Nutrient Requirements of Dairy Cattle. 7th Rev. Ed., Natl. Acad. Press, Washington, DC.

SAS/STAT ${ }^{\circledR}$ User's Guide, Version 8. 1999. SAS Inst., Inc., Cary, NC.

Schauff, D. J., and J. H. Clark. 1992. Effects of feeding diets containing calcium salts of long-chain fatty acids to lactating dairy cows. J. Dairy Sci. 75:2990-3002.

Sukhija, P. S., and D. L. Palmquist. 1988. Rapid method for determination of total fatty acid content and composition of feedstuffs and feces. J. Agric. Food Chem. 36:1202-1206.

Supelco. 1975. GC separation of VFA C2-C5, Bulletin 749D. Supelco, Inc., Bellefonte, PA

Tyrrell, H. F., and P. W. Moe. 1975. Effect of intake on digestive efficiency. J. Dairy Sci. 58:1151-1163.

Van Soest, P. J. 1982. Nutritional Ecology of the Ruminant. O \& B Books, Inc., Corvalis, OR.

Van Soest, P. J., J. B. Robertson, and B. A. Lewis. 1991. Methods for dietary fiber, neutral detergent fiber, and nonstarch polysaccharides in relation to animal nutrition. J. Dairy Sci. 74:35833597.

Weisbjerg, M. R., T. Hvelplund, and C. F. Børsting. 1992. Digestibility of fatty acids in the gastrointestinal tract of dairy cows fed with tallow or saturated fats rich in stearic acid or palmitic acid. Acta Agric. Scand. Sect. A Anim. Sci. 42:115-120.

Weiss, W. P., and D. J. Wyatt. 2000. Effect of oil content and kernel processing of corn silage on digestibility and milk production by dairy cows. J. Dairy Sci. 83:351-358. 